\title{
A Pécsi Tudományegyetem Egyetemi Könyvtár és Tudásközpont feldolgozási gyakorlata a tartami feltárás tükrében
}

Írásomban bemutatom, hogyan változott a Pécsi Tudományegyetem Egyetemi Könyvtár és Tudásközpont Központi Könyvtárában a tartalmi feltárás gyakorlata az 1970-es évektől egészen napjainkig.

A pécsi egyetem szervezeti változásait követve az Egyetemi Könyvtár könyvtári hálózata is többször módosult. Az 1970-es években az addig csak az Állam- és Jogtudományi Karral rendelkező Pécsi Tudományegyetemen megalapították a Közgazdaságtudományi Kart, s ezek mellett önálló intézményként müködött még a Pécsi Tanárképző Főiskola, a Pollack Mihály Műszaki Főiskola és a Pécsi Orvostudományi Egyetem. ${ }^{1}$

\section{A szakreferensi rendszer kialakulása, virágkora és megszünése}

Az 1970-es évek közepén a Központi Könyvtár tájékoztató szakemberei végezték a tartalmi feltárást, majd a Jogi- és Közgazdaságtudományi Kar szakreferenseivel kiegészülve Szakreferensi Osztályként müködtek, ennek keretein belül folytatták tovább a tartalmi feltárást. Az új igazgató elkötelezett híve volt annak, hogy a Szakreferensi Osztály keretei között társadalomtudományi kutatóbázis alakuljon ki: elképzelése az volt, hogy a tudományos tevékenységet folytató kutatók vegyenek részt a szakterületüknek megfelelő szakreferensi munkában. Igazi szakemberek kerültek erre az osztályra: a Baranya Megyei Levéltárból könyvtároslevéltáros-történész, a Dunántúli Tudományos Intézetből jogász-szociológus kolléganő, akik könyvtári munkakörük mellett tudományos tevékenységüket is folytatták. A tudományos tevékenységet a föigazgató kutatónapokkal támogatta, és szorgalmazta a külföldi tanulmányutakat (pl. Hollandiába, Grazba). ${ }^{2}$

A tartalmi feltárást az adott tudományterület szakemberei végezték a maguk alakította tárgyszavakkal. A szakreferensek szakterületi képzettséggel rendelkeztek, könyvtárosival nem. Ez a gyakorlat jól müködött, mert a szakterület „tudósai” voltak, a kapcsolódó terminológia ismerete nagy előnyt jelentett. A karok oktatóit

\footnotetext{
${ }^{1}$ „Gazdagabban távozz, térj vissza gyakrabban!”: Mérföldkövek a Pécsi Tudományegyetem Egyetemi Könyvtár és Tudásközpont történetében. Pécs, PTE EK TK. 2018. 6-7. p. https://www. lib.pte.hu/sites/docs/polc/documents/fda-schmelczerpohanka-szeberenyi-gazdagabban-tavozzterj-vissza-gyakrabban-pteektk-pecs-2018/pdf/fda-schmelczerpohanka-szeberenyi-gazdagabbantavozz-terj-vissza-gyakrabban-pteektk-pecs-2018.pdf (2019. július 25.)

2 Ádámné Babics Anna: Amire jó emlékezni...: A Jogtudományi, majd Szakreferensi Osztály tevékenységéről és munkatársairól. = Ünnepi tanulmányok Móró Mária Anna tiszteletére. Szerk. Kokovai Szabina - Pohánka Éva. Pécs, Pécsi Tudományegyetem Könyvtára. 2009. 22. p.
} 
és hallgatóit magas színvonalon tájékoztatták a maguk feldolgozta állományból, melynek köszönhetően nagyobb szerepet kaptak a személyre szóló tájékoztatási szolgáltatások, valamint közvetlenebb kapcsolat alakulhatott ki a könyvtárosok és a könyvtárhasználók között. Ekkor együtt volt könyvtárunkban az egyes tudományterületekhez kapcsolódó szaktudás (szakreferensek) és a könyvtáros szakmai ismeret (könyvtáros végzettségü munkatársak), ezért ideális időszak lehetett volna egy önálló tárgyszórendszer kidolgozásának megkezdésére.

A szakreferensek feladatai:

- az oktatók, hallgatók igényeinek felmérése,

- könyvtári tájékoztatás,

- az állományépítés szakmai irányítása, az adott tudományterületeken az oktatók bevonásával,

- a szakkatalógus szerkesztése,

- szakbibliográfiák összeállítása,

- hallgatók könyvtári ismeretekre oktatása,

- oktatók publikációs tevékenységéről bibliográfiák összeállítása, ${ }^{3}$

- tartalmi feltárás - ETO, tárgyszó.

1982-ben a Tanárképző Kar csatlakozásával megalakuló egyetem felvette Janus Pannonius nevét. 1992-ben a Tanárképző Kar helyén önálló Bölcsészettudományi és Természettudományi Karok alakultak, az egyetem ekkor négy karból állt. 1995-ben a Pollack Mihály Müszaki Főiskola csatlakozott a Janus Pannonius Tudományegyetemhez, majd 1996-ban létrejött az egyetem hatodik kara, a Müvészeti Kar. A Pécsi Orvostudományi Egyetem önálló intézményként müködött, kiegészülve az Egészségtudományi Főiskolai Karral. ${ }^{4}$

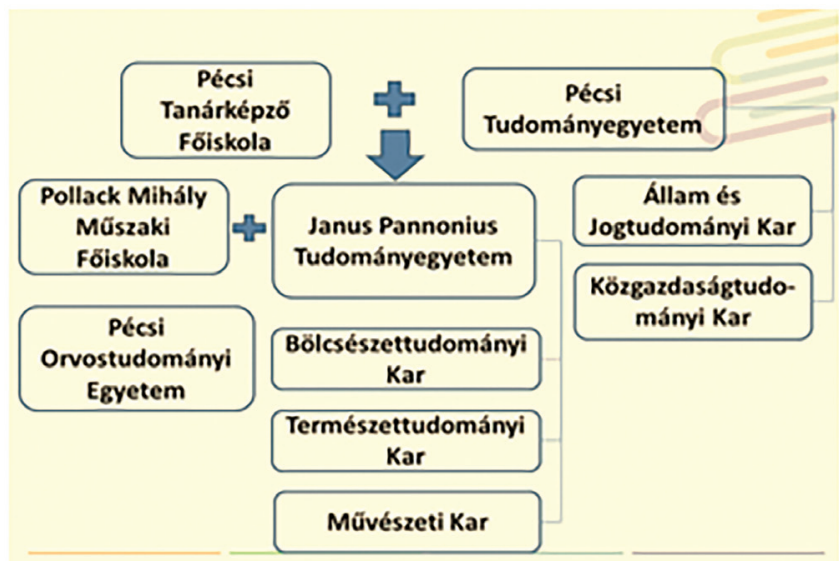

1. ábra. Az egyetem szervezeti alakulása

\footnotetext{
${ }^{3}$ Ádámné Babics Anna: i. m. 17. p.

${ }^{4}$ „Gazdagabban távozz, térj vissza gyakrabban!”: i. m. 6-25. p.
} 
A kilencvenes évekre a Pécsi Egyetemi Könyvtár hat szervezeti egységéből négyben önálló feldolgozás folyt, ezt a széttagoltságot azonban célszerünek látszott megszüntetni. Ekkor még nem volt integrált könyvtári rendszer, de a megvásárlása, egy közös adatbázis építése tervben volt. Ezzel párhuzamosan észszerűnek tünt a feldolgozás központosítása is.

Ebben az időszakban fordulat következett be a könyvtárak életében, amelyben szerepet játszottak a könyvtári munkában, feladatokban és könyvtárhasználatban szükségszerủen végbement változások is. Kialakulóban volt az internet jelentette új világ elektronikus és önkiszolgáló könyvtári modellje, helyi szinten pedig a több karból álló egyetemnek és a nagy létszámú hallgatóságnak jobban megfelelő könyvtári szervezet. A Szakreferensi Osztály átszervezéssel megszünt, egy központosított gyarapító-feldolgozó osztály alakult, amely átvette a szakozás-tárgyszavazás feladatát. Ekkor került a Bölcsészettudományi és Természettudományi Kari Könyvtár állományának feldolgozása a Központi Könyvtárhoz. ${ }^{5}$

A szakreferensek egy része ugyanakkor fokozatosan elvándorolt a könyvtárból - egyetemi oktatói pályára léptek, vagy egyéb, a szakterületükhöz kapcsolódó munkakörben helyezkedtek el. De maradt olyan kolléga, aki szaktájékoztató munkakörben dolgozva a tudományos tevékenységét is folytatta. ${ }^{6}$

Ebben az időszakban a szaktájékoztatók feladata volt a tartalmi feltárás, a tájékoztatás és a szakkatalógus gondozása. Segédletként ETO-táblázatot, kézikönyveket (lexikonokat, szótárakat) használtak a szabad tárgyszavak kialakításához. Voltak ugyan törekvések egy saját tárgyszórendszer létrehozására, de ez nem valósult meg. Az 1980-as években visszakeresésre alkalmas tárgyszavas jegyzéket dolgozott ki a Központi Könyvtár feldolgozó osztálya, amit 1990-ben átdolgoztak. Az 1990-es évek közepén egy munkatársunk elkezdte a saját szakterületéhez tartozó tárgyszavak meghatározását és egy tárgyszórendszer felépítését, de a hiányzó szakterületekhez tartozó tárgyszavak kidolgozásának elmaradása miatt a szabad tárgyszavakkal való tartalmi feltárást folytattuk. A pécsi Egyetemi Könyvtár stratégiai tervében Sonnevend Péter így ír: „Kényesebb kérdés a tárgyi feldolgozás. Könyvtárainkban a szakozás mellett tárgyszavazunk is, meglehet, kicsit változó minöséggel, hisz szabad tárgyszavakkal élünk. Az országos, általános tárgyszórendszer munkálata - gondolata - tekintetében kissé szkeptikus vagyok, mivel egyrészt nagyon nagy vállalkozás, másrészt a nagykönyvtárak és elsö helyen az OSZK harmonikus együttmunkálkodása nélkülözhetetlen feltétel'. ${ }^{7}$

\footnotetext{
${ }^{5}$ Pintér László: Múlt, jelen, jövő (JPTE Könyvtár Feldolgozó Osztály). = Pécsi Könyv-és Infotár, 1. évf. 1996. 7. sz. 13-16. p.

${ }^{6}$ Ádámné Babics Anna: i. m. 25. p.

${ }^{7}$ Sonnevend Péter: A Pécsi Egyetemi Könyvtár stratégiai terve. = Könyvtári Figyelö, 42. évf. 1996. 4. sz. 623-629. p.
} 
A számítógépes könyvtári programok elterjedésével könnyebbé vált a munka. A katalogizálási modul szolgált a dokumentumok adatainak bevitelére. Ebben a modulban történik a tartalmi feltárás is, melyet továbbra is szabad tárgyszavakkal határozunk meg, kiegészülve az ETO jelzettel, szakjelzettel, valamint a raktári jelzettel, melyeket a bibliográfia rekord megadott mezőjébe rögzítünk. A Jogi- és a Közgazdaságtudományi Kari Könyvtárban - a korábbi gyakorlatot megtartva - a tartalmi feltárást jogász, illetve közgazdász végzettségü szakember végezte.

\section{Az egyetemi integráció hatása a gyüjteményszervezési munkafolyamatokra} 2000-ben a felsőoktatási integráció eredményeként a Janus Pannonius Tudományegyetem, a Pécsi Orvostudományi Egyetem és a szekszárdi Illyés Gyula Pedagógiai Főiskola egyesülésével létrejött a Pécsi Tudományegyetem. ${ }^{8}$ A három jogelőd intézmény egyesülésekor azok könyvtárai is integrálódtak, az addig elkülönülten müködő szakkönyvtárak egységes központi irányítás alá kerültek.

Jelenleg az - időközben Pekár Mihály professzor nevét felvevő - Orvosés Élettudományi Szakkönyvtárban az Egészségtudományi Kar négy képzési központjának (Pécs, Kaposvár, Szombathely, Zalaegerszeg) könyvtáraiban, és a szekszárdi Kultúratudományi, Pedagógusképző- és Vidékfejlesztési Kar Könyvtárában ${ }^{9}$ folyik önálló feldolgozás.

A tartalmi feltárást továbbra is a tudományterületek szakemberei végzik, de nincs minden tudományterületnek saját szakfelelőse, ezért egy-egy emberhez olyan területek is tartoznak, amelyre vonatkozóan nincs szakirányú végzettsége.

Az integrált könyvtári rendszerben (Corvina) a könyvtári hálózatnak egy közös katalógusa van. Az önálló feldolgozást folytató egységek állománya - a szekszárdi, kaposvári, szombathelyi egységek kivételével - a PTE elektronikus katalógusában jelenik meg. A különböző intézményi és könyvtári előzmények eredményeként duplum rekordokkal és a jelzetek különbözőségével kellett szembenézni. Ekkor a közös katalógust a PTE Központi Könyvtára és a kari könyvtárak hálózata használta, majd 2009 elején a Városi Könyvtár konvertálta állományát a CORVINA-ba, 2010 elején a Megyei-Városi Könyvtár állományainak összevonására került sor. Egyetlen közös katalógust használunk, amely az adatbázisok összevonása miatt folyamatosan bővül.

Az egységesítésre való törekvés megmaradt, de a tárgyszórendszer hiánya továbbra is gondot jelentett. Ebben az időszakban merült fel a Debreceni Egyetem Egyetemi és Nemzeti Könyvtár által használt tárgyszórendszer átvételének gondolata.

\footnotetext{
${ }^{8}$ „Gazdagabban távozz, térj vissza gyakrabban!”: i. m. 4. p.

${ }^{9}$ A Felnőttképzési és Emberi Erőforrás Fejlesztési Kar és a szekszárdi Illyés Gyula Kar öszszevonásával létrejön a Kultúratudományi, Pedagógusképző és Vidékfejlesztési Kar.
} 


\section{A Dél-Dunántúli Regionális Könyvtár és Tudásközpont létrejötte}

A következő jelentős változás 2010-ben, a Dél-Dunántúli Regionális Könyvtár és Tudásközpont ${ }^{10}$ létrejötte volt, amikor a Csorba Győző (megyei-városi) Könyvtár, a Pécsi Tudományegyetem Központi Könyvtára és a Pécsi Tudományegyetem Benedek Ferenc Jogtudományi és Közgazdaságtudományi Szakkönyvtára egyesült egy közös épületben, közös szolgáltatásokkal.

Mind a megyei-városi feladatkörü Csorba Győző Könyvtár, mind a PTE Egyetemi Könyvtár saját könyvtári hálózatot müködtet: a Csorba Győző Könyvtár a kistérségi és a Pécs városi könyvtári hálózatát, az Egyetemi Könyvtár pedig a kari, intézeti, tanszéki és klinikai könyvtári hálózatot.

Mindkét könyvtárnak saját gyüjteményszervezési osztálya van. A két osztály a munkáját összehangoltan, szoros munkakapcsolatban végzi, a közös Corvina integrált könyvtári rendszer segítségével egy közös adatbázist építünk. A könyvtárak csak a saját, illetve a hálózatába tartozó könyvtárak részére beszerzett dokumentumokat dolgozzák fel.

Összeolvadt tehát egy felsőoktatási és egy közkönyvtár, folyamatosan bővülő-átalakuló hálózattal. Az online katalógusunkban így újabb duplumok, eltérő jelzetek, tárgyszavak keletkeztek. Emiatt duplumszürést végeztünk, de jelenleg még mintegy 200.000 duplumgyanús rekordot mutat a lekérdezés. Mindez a könyvtárhasználók számára komoly nehézséget okoz: az eltérő minőségü duplumrekordokhoz tartozó több száz példánylelőhely közül a megfelelő kiválasztása adott esetben rendkívül időigényes.

Jelenleg folyamatban van két, szintén Corvinát használó könyvtári egység, a szekszárdi Kultúratudományi, Pedagógusképző és Vidékfejlesztési Kar Könyvtára, valamint az Egészségtudományi Kar Kaposvári Képzési Központ Könyvtára állományainak beolvasztása a közös katalógusba.

\section{Az új tárgyszórendszer kihívásai}

Az Egyetemi Könyvtár és Tudásközpont Gyüjteményszervezési Osztályának létszáma jelenleg 12 fö. Feladatuk a hagyományos dokumentumok, folyóiratok, könyvek beszerzése, feldolgozása, szerelése és továbbítása a kari egységeknek. Az osztály munkatársai a Tudásközpont hétvégi olvasószolgálati ügyeletében is részt vesznek.

Tartalmi feltárást jelenleg két fö (közgazdász-történész; földrajz-rajz szakos tanár, írónő) végez, nem teljes munkaidőben. Ök a tudományterületeket egymás között a szakképzettségüknek megfelelően megosztva gondozzák. A jogi tartalmi feltárást jogi végzettségü kolléga végezte, aki 2017-ben vezető pozícióba került. Esély sem volt rá, hogy hasonló végzettségü szakembert találjunk a feladatra, így a joghoz kötődő, de bölcsész diplomával rendelkező munkatárs vette át a szakozás munkafolyamatát.

\footnotetext{
${ }^{10}$ „Gazdagabban távozz, térj vissza gyakrabban!”: i. m. 36-37. p.
} 
2017-ben aláírtuk az együttmúködési megállapodást a Debreceni Egyetem Egyetemi és Nemzeti Könyvtárral az általuk használt tárgyszórendszer magyar változatának használatba vételéről. Az informatikai egyeztetések eredményeként 2019 áprilisában a tárgyszórekordok a PTE katalógusának háttér authority állományába kerültek.

A betöltés óta a Gyüjteményszervezési Osztály a tartalmi feltárást a debreceni tárgyszavakkal végzi, egyeztetve a Csorba Győző Könyvtár munkatársaival - mivel az elektronikus katalógusunk közös, és próbálunk hasonló elvek alapján dolgozni. Az új gyakorlat időigényesebb, a korábbinál egyelőre lassabb tartalmi feltárást eredményez.

Abban az esetben, ha a debreceni kollégák által készített bibliográfiai rekord még nem tartalmaz egységesített tárgyszót, vagy az nekünk nem megfelelö, akkor szabad tárgyszavakkal egészítjük ki a leírást, így a kettő egymást erősítve válik ideálissá, felhasználóbaráttá.

A szabad tárgyszó használatának azért is van jelentősége, mert az olvasók a Google kulcsszavas kereséséhez szoktak. Böngészés esetén csak az egységesített tárgyszavakra lehet keresni, szabad tárgyszavakra nem. Az egységesített tárgyszavak közötti böngészést csak a könyvtárosok használják, tapasztalataink szerint az olvasók nehezen boldogulnak vele, mivel nem ismerik.

Kihasználva a tárgyszórendszer egyik nagy előnyét, az elektronikus katalógusunkat úgy állítottuk be, hogy szerző és tárgyszó esetén az utalókra is lehessen keresni. Így nemcsak böngészéskor, hanem kulcsszavas keresés esetén is elöjönnek a találatok.

\section{Összegzés}

A tartalmi feltárás kétségtelenül gyenge láncszem könyvtárunkban, de érezzük, hogy változtatni kell. Kérdés, milyen irányba tegyük. Arról értesültünk ugyanakkor, hogy más könyvtárakban is hasonló problémák merülnek fel, s ez meggyőzött minket arról, hogy beszélni kell a tartalmi feltárás nehézségeiről. Vannak nyitott kérdések, egyes problémákra nincs még végleges megoldás, ezért tapasztalatot szerzünk.

\section{Rezümé}

Tanulmányomban a tartalmi feltárás gyakorlatát középpontba helyezve mutatom be a Tudásközpont kialakulásához vezető utat, annak föbb mérföldköveit és a jelenlegi helyzetből adódó kihívásokat a következő szempontok szerint: a szakreferensi rendszer kialakulása, virágkora és megszünése, az egyetemi integráció hatása a gyüjteményszervezési munkafolyamatokra, a 2010-ben létrejött új integrált könyvtár okozta átalakulás, problémák és folyamatos változások. 


\section{Processing practice of the University of Pécs University Library and Centre for Learning in the light of subject indexing}

Focusing on the practice of content classification, I present the path to the Centre for Learning, its major milestones, and the challenges of the current situation in the following aspects; the emergence, flowering and termination of the subject librarians system; the impact of university integration on collection organization workflows; transformation due to the new integrated library created in 2010; problems and constant changes.

BERTÁNÉ NÉMETh ÁGNES osztályvezető

PTE Egyetemi Könyvtár és Tudásközpont 